\title{
Footshock-Induced Abstinence from Compulsive Methamphetamine Self-administration in Rat Model Is Accompanied by Increased Hippocampal Expression of Cannabinoid Receptors (CB1 and CB2)
}

\author{
Subramaniam Jayanthi ${ }^{1}$ (D) $\cdot$ Ritvik Peesapati $^{1} \cdot$ Michael T. McCoy $^{1}$ (D) Bruce Ladenheim $^{1} \cdot$ Jean $_{\text {Lud }}$ Cadet $^{1}$ (D
}

Received: 19 August 2021 / Accepted: 17 November 2021 / Published online: 3 January 2022

This is a U.S. government work and not under copyright protection in the U.S.; foreign copyright protection may apply 2021

\begin{abstract}
Methamphetamine (METH) use disorder (MUD) is characterized by compulsive and repeated drug taking despite negative life consequences. Large intake of METH in humans and animals is accompanied by dysfunctions in learning and memory processes. The endocannabinoid system (ECS) is known to modulate synaptic plasticity and cognitive functions. In addition, the ECS has been implicated in some of the manifestations of substance use disorders (SUDs). We therefore sought to identify potential changes in the expression of various enzymes and of the receptors (CB1 and CB2) that are members of that system. Herein, we used a model of METH self-administration (SA) that includes a punishment phase (footshocks) that helps to separate rats into a compulsive METH phenotype (compulsive) that continues to take METH and a non-compulsive METH (abstinent) group that suppressed or stopped taking METH. Animals were euthanized $2 \mathrm{~h}$ after the last METH SA session and their hippocampi were used to measure mRNA levels of cannabinoid receptors $(\mathrm{CB} / \mathrm{Cnr})$, as well as those of synthesizing (DAGL-A, DAGL-B, NAPEPLD) and metabolizing (MGLL, FAAH, PTGS2) enzymes of the endocannabinoid cascade. Non-compulsive rats exhibited significant increased hippocampal expression of $\mathrm{CB} 1 / \mathrm{Cnrl}$ and $\mathrm{CB} 2 / \mathrm{Cnr} 2$ mRNAs. mRNA levels of the synthesizing enzyme, DAGL-A, and of the metabolic enzymes, MGLL and FAAH, were also increased. Non-compulsive rats also exhibited a significant decrease in hippocampal Ptgs $2 \mathrm{mRNA}$ levels. Taken together, these observations implicate the hippocampal endocannabinoid system in the suppression of METH intake in the presence of adverse consequences.
\end{abstract}

Keywords Abstinence $\cdot$ Addiction $\cdot$ Cannabinoid receptors $\cdot$ Endocannabinoid $\cdot$ Footshocks $\cdot$ Hippocampus · Methamphetamine $\cdot$ Methamphetamine use disorder $\cdot$ Neuroprotection

$\begin{array}{ll}\text { Abbreviations } \\ \text { 2-AG } & \text { 2-Arachidonoylglycerol } \\ \text { AEA } & \text { Anandamide } \\ \text { CB/Cnr } & \text { Cannabinoid receptor } \\ \text { CT } & \text { Control group } \\ \text { DAGL } & \text { Diacylglycerol lipase } \\ \text { eCB } & \text { Endocannabinoid } \\ \text { ECS } & \text { Endocannabinoid system } \\ \text { FAAH } & \text { Fatty acid amide hydrolase }\end{array}$

Subramaniam Jayanthi and Ritvik Peesapati are contributed equally in this work.

$\begin{array}{ll}\text { METH } & \text { Methamphetamine } \\ \text { MGLL } & \begin{array}{l}\text { Monoglyceride lipase } \\ \text { NAPEPLD }\end{array} \\ & \begin{array}{l}\text { Nocyl phosphatidylethanolamine } \\ \text { phospholipase-D }\end{array} \\ \text { NAc } & \text { Nucleus accumbens } \\ \text { PTGS2 } & \text { Prostaglandin-endoperoxide synthase 2 } \\ \text { SA } & \text { Self-administration } \\ \text { SR } & \text { Shock-resistant group } \\ \text { SS } & \text { Shock-sensitive group } \\ \text { THC } & \text { Tetrahydrocannabinol } \\ \text { YSR } & \text { Yoke shock resistant } \\ \text { YSS } & \text { Yoke shock sensitive }\end{array}$

Jean Lud Cadet

jcadet@intra.nida.nih.gov

Molecular Neuropsychiatry Research Branch, DHHS/ NIH/NIDA Intramural Research Program, 251 Bayview Boulevard, Baltimore, MD 21224, USA 


\section{Introduction}

Methamphetamine (METH) is the most commonly used amphetamine-type stimulant (ATS) worldwide. About 1.6 million American adults aged 18 years or older had reported METH use between 2015 and 2018 [1]. Among these users, about 53\% were reported to meet criteria for a METH use disorder (MUD) [1]. The acute behavioral effects of the drug are thought to be related to the fact that METH administration induces sustained dopamine (DA) release in the synaptic cleft [2,3], with subsequent interactions with DA receptors $[4,5]$ that are located in various regions of the brain [6]. Importantly, repeated injections of METH can produce reactive oxygen species (ROS) [7, 8] that can alter the integrity of the brain structures [9] that are important for cognitive functions including learning and memory [10].

In addition to the effects on dopaminergic systems, a potential role of the endocannabinoid system (ECS) in the behavioral manifestations of rewarding drugs has been proposed [11-13]. The ECS is a bioactive lipid-based signaling pathway that includes cannabinoid receptors (CB1 and CB2) and the endogenous cannabinoids (eCBs), 2-arachidonoylglycerol (2-AG) and arachidonyl ethanolamide (AEA, anandamide) [14-16]. This system also includes synthesizing and degrading enzymes [17-21]. The eCBs are synthesized "on demand" by the enzymes diacylglycerol lipases (DAGL-A and DAGL-B) and N-acyl phosphotidylethanolamine phospholipase-D (NAPEPLD) that mediate the synthesis of 2-AG and AEA, respectively $[19,20]$. 2-AG and AEA are, in turn, broken down by metabolic enzymes that are monoglyceride lipase (MGLL), fatty acid amide hydrolase (FAAH), and prostaglandin-endoperoxide synthase 2 (PTGS2) [17, 18, 21]. Both 2-AG and AEA bind to cannabinoid receptors (CB/Cnr) to facilitate downstream molecular changes [22].

Accumulating evidence suggests that eCBs (2-AG and AEA) modulate long-term synaptic plasticity in various brain regions [23]. However, the brain concentration of 2-AG is 170-fold higher than that of AEA [24], suggesting that 2-AG might play a primary role in the functions of that system in the brain. In addition, 2-AG binds preferentially to $\mathrm{CB} 1$ receptors in the hippocampus. $\mathrm{CB} 1$ receptors are expressed in GABAergic interneurons and glutamatergic axon terminals (reviewed by Kruk-Slomka et al. [14]) and modulate the maintenance of homeostatic eCB signaling [25] that is known to influence drug reward in various models [26, 27]. Owing to their localization, CB1 receptors participate in memory functions, stress, fear, and anxiety [28-30] by regulating neuronal signaling and synaptic plasticity [31]. Hippocampal eCB signaling is dependent on duration of the ligand in the synapse and ligand-CB1 binding efficacy. Importantly, the levels of eCBs in the brain are controlled by enzymatic degradation [32-36].
The discussion above thus indicated that the ECS signaling cascade could be either stimulated or inhibited in order to alter METH-induced neuroadaptation in preclinical models and as potential therapeutic approaches to counter MUD in humans. We were therefore interested in identifying potential effects of METH self-administration (SA) on ECS expression in the rats that can be consistently separated into compulsive and non-compulsive METH takers after the application of footshocks during METH SA [37-40]

\section{Materials and Methods}

\section{Animals and Drug Treatment}

We used 350-400 g male Sprague-Dawley rats from Charles River Labs, Raleigh, NC, USA, that were maintained in a temperature and humidity-controlled room $\left(22.2 \pm 0.2^{\circ} \mathrm{C}\right)$ with sufficient access to food and water. The National Institute of Drug Abuse Animal Care and Use Committee approved our procedures that followed the Guide for the Care and Use of Laboratory Animals (ISBN 0-309-05,377-3).

\section{Intravenous Surgery}

Using ketamine and xylazine (100 and $5 \mathrm{mg} / \mathrm{kg}$, i.p., respectively), we anesthetized rats and placed silastic catheters into the jugular veins [38]. After surgery, the rats were monitored for health daily and the catheters were flushed every other day with sterile saline containing gentamicin $(5 \mathrm{mg} / \mathrm{ml}$; Butler Schein) and allowed to recover for 5-10 days before METH SA training. Rats received meloxicam ( $1 \mathrm{mg} / \mathrm{kg}$, sc.) for analgesia upon awake from anesthesia and a second dose the following day.

\section{Training and Punishment Phases}

METH self-administration training procedure is as previously described $[38,41]$. Self-administration training was conducted in operant chambers equipped with two response levers - the "active" lever activates the infusion pump while inactive lever presses had no such program. In all the chambers, the rats were free to consume food and water from the feeders and water bottles hanging on the walls. Each press on the active lever will result in an infusion of dl-METH $\mathrm{HCl}$ $(0.1 \mathrm{mg} / \mathrm{kg} /$ infusion$)$ delivered at a volume of $0.1 \mathrm{ml}$ during a 2-3-s period, accompanied by a 5-s compound tone-light stimulus. We used a fixed-ratio-1 schedule with 20-s timeout period designed to prevent drug overdose. The SA session lasted for $9 \mathrm{~h} /$ day (three 3-h sessions/day, each separated by 30 min off intervals) for 21 days. At the end of each 3-h session, the house light was turned off, and the active lever was retracted. For all rats, lever presses on the inactive lever are 
recorded but have no programmed consequences. In order to minimize weight loss, rats were trained in sets of 5 days of METH SA with 2 days off. During off days, rats were housed in the SA chambers disconnected from the intravenous SA lines.

The training conditions for the drug-naïve rats (controls, $\mathrm{CT}$ ) will be the same as the METH-trained rats except sterile saline is infused after the press of the "active" lever.

Utilizing identical conditions as described above, rats continued METH SA during the punishment phase. Additionally, $50 \%$ of the reinforced lever presses for METH resulted in a simultaneous delivery of a 0.5 -s footshock through the grid floor. The footshock currents were set to $0.18 \mathrm{~mA}$ on day $1,0.24 \mathrm{~mA}$ on day $2,0.30 \mathrm{~mA}$ on days 3 to 5 , and $0.36 \mathrm{~mA}$ on days 6 to 8 . The application of this shock intensity range has been shown to separate rats into shock-sensitive (SS) and shock-resistant (SR) animals [38, 42]. Furthermore, as a control for the effects of shock on biochemical and molecular markers within the brain, some saline rats will be yoked to the METH-trained rats that receive contingent shocks. The saline rats will also receive a footshock each time METH-trained animals received a contingent shock. There were separate groups of rats that were yoked to the corresponding shock-resistant (YSR) and shock-sensitive (YSS) rats, respectively.

\section{RNA Extraction}

Using a guillotine $2 \mathrm{~h}$ after the last day of SA and footshocks, we euthanized the rats by decapitation and isolated hippocampus, nucleus accumbens (NAc), and mid-brain from the brains. Using Qiagen RNeasy Mini kit (Qiagen, Valencia, CA, USA), we were able to extract total RNA from individual brain samples of all the five groups (CT; SR; SS; YSR; YSS) and assessed its integrity with an Agilent 2100 Bioanalyzer (Agilent, Palo Alto, CA, USA); RNA samples showed no degradation and the RNA integrity numbers were $>8.0$.

\section{Quantitative RT-PCR Analysis of mRNA Levels}

Using Advantage RT-for-PCR kit (Clontech, Mountain View, CA, USA), we reverse-transcribed $500 \mathrm{ng}$ of total RNA from the CT group $(n=9)$, SR group $(n=8)$, SS group $(n=7)$, YSR group $(n=12)$, and YSS $(n=8)$ into cDNA. Quantitative polymerase chain reaction (PCR) was carried out as described by our published protocol [43]. The genespecific primers were synthesized from the Synthesis and Sequencing Facility of Johns Hopkins University (Baltimore, MD, USA) based on the PCR primers we generated using LightCycler probe design software v. 2.0 (Roche Biosystems, Indianapolis, IN, USA). The list of primers used is given in Table S1. Quantitative reverse transcription PCR was performed using the Roche LightCycler 480 II with iQ SYBR Green Supermix (Bio-Rad). A standard curve method was used to determine the concentration of unknown samples. The raw data was obtained using a second derivative maximum analysis via a non-linear, polynomial regression line (Roche Light cycler software). Data reported uses absolute quantification. Within each sample, the relative amounts of mRNA analyzed were normalized using two reference genes Clathrin and $18 S$. The results are shown as fold changes calculated as the ratios of normalized gene expression data for METH-treated groups (SR and SS) compared to its respective yoked shock groups (YSR and YSS) and to the CT control group.

\section{Statistical Analysis}

Behavioral and RT-PCR data were analyzed using Prism ${ }^{\circledR}$ version 6 (San Diego, CA). Behavioral data were analyzed using repeated measures two-way ANOVA. The dependent variable was the total number of METH infusions for each group on each day. Independent variables were the withinsubject factor group (SS or SR), between-subject factor training session duration, and their interactions. Bonferroni post hoc tests were used to compare METH intake between SS and SR groups. RT-PCR data were analyzed using oneway analysis of variance (ANOVA) followed by Fisher's PLSD post hoc test. ANOVA was also used to analyze the total number of shocks received by the yoked shock groups. Statistical significance for all tests was set at $p<0.05$.

\section{Results}

\section{Effects of Footshocks on METH Infusion}

As reported in Subu et al. [40], rats were first trained for 21 days of METH SA (SA training phase) prior to the application of 8 days of contingent footshocks. The experimental paradigm is shown in Fig. 1a. Contingent footshocks separated METH SA rats into shock-sensitive (SS, non-compulsive, $n=7$ ) and shock-resistant (SR, compulsive, $n=8$ ) groups. SS rats significantly decreased their METH intake during the shock phase whereas the SR rats continued to compulsively press the lever to obtain METH. The control (CT, $n=9)$ and rats yoked to SR and SS during the footshock regimen (YSR-yoked shock resistant, $n=12$; YSS-yoked shock sensitive, $n=8$ ) self-administered saline solution throughout the experiment. The box and whisker plots in Fig. 1b show that there were no significant differences in total METH intake between SR and SS rats during the escalation (weeks 1 and 2; SR: $8.0 \pm 0.1$, SS: $5.8 \pm 0.05$ ) and maintenance phases (weeks 3 and 4; SR: $11.8 \pm 0.1$, SS: $10.0 \pm 0.1)$ of METH SA. In contrast, 
Fig. 1 The behavioral effect of contingent footshock punishment on METH intake. The experimental timeline is given (a), where rats self-administered METH for 21 days followed by footshocks for 8 days. The drug-naïve control rats (CT) will be the same as the METHtrained rats except sterile saline is infused after the active lever press. The control animals for footshock also received saline but were yoked to the METH-trained rats that receive contingent shocks. There were separate groups of rats that were yoked to the corresponding METH shock-resistant (SR) and shock-sensitive (SS) rats. They are termed YSR and YSS, respectively. (b) Box and whisker plot shows that during weeks 1 and 2 rats given access to METH slowly increased their drug intake (escalation phase). By weeks 3 and 4, the METH intake plateaued (maintenance phase). Total METH intake between shock-resistant (SR, $n=8$, shown as red) and shocksensitive (SS, $n=7$, shown as blue) rats did not significantly differ during these escalation and maintenance phases. (c) Following the footshock punishment, SS rats significantly decreased their total METH intake $(p<0.0001)$, while the SR rats did not. (d) The column bar graph shows the number of footshocks received by the animals. The SS and yoked shock-sensitive (YSS) rats received a significantly lower number of footshocks compared to the SR and yoked shockresistant (YSR) rats $(p<0.001)$. (e) The table depicts the average number of METH infusions consumed by rats during both the training and punishment phases a

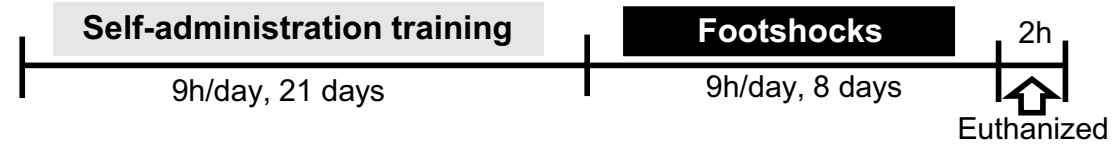

b

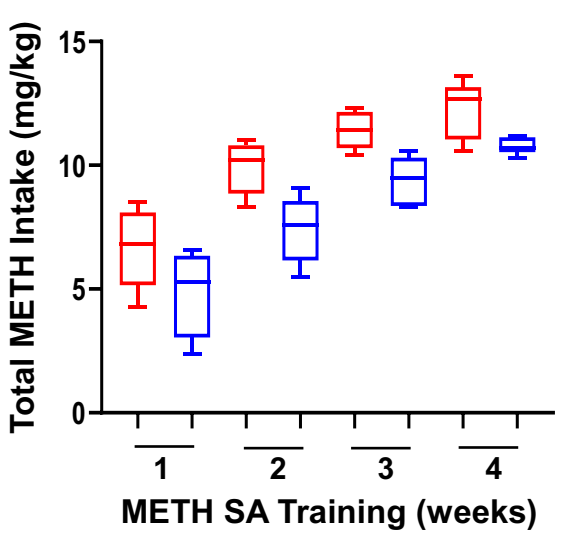

C

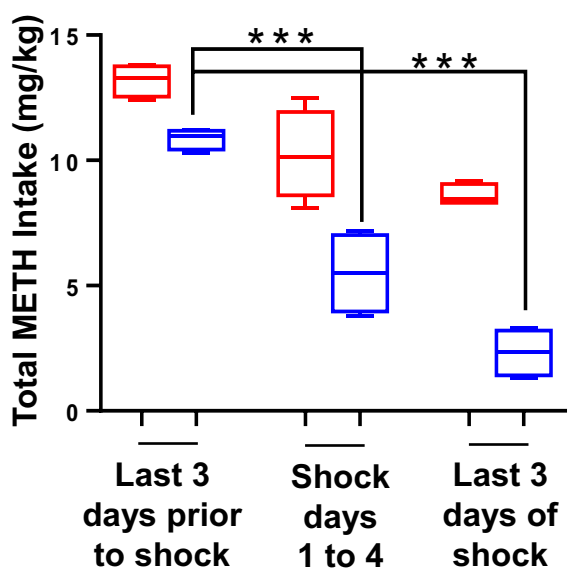

e

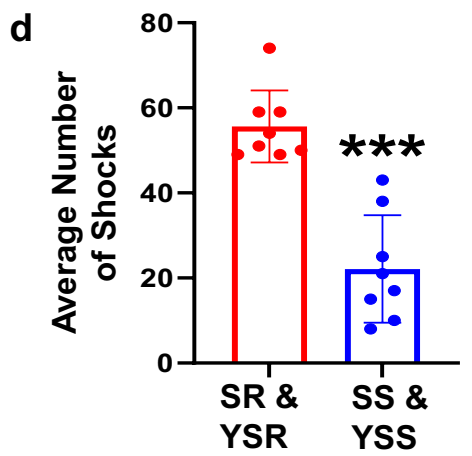

following footshocks, SS rats self-administered significantly lower amounts of METH than SR rats (Fig. 1c). Total METH intake for SR rats on the last 3 days prior to shock $(13.5 \pm 0.8)$ did not significantly differ from the last 3 days of shock $(11.1 \pm 0.11)$. However, significant decreases in total METH intake were observed for SS rats, with intake over the last 3 days of shock $(2.5 \pm 0.3)$ being markedly lower than the 3 days prior to shock $(10.8 \pm 0.10)$ (see Fig. 1c). Figure 1d shows that there was a lower number of footshocks received by the SS and YSS rats in comparison to the SR and YSR rats $(p<0.001)$. Figure $1 \mathrm{e}$ illustrates the actual number of METH infusions taken by 
the rats during both the training and shock phases of the behavioral experiment.

\section{Effects of METH SA and Contingent Footshock on mRNA Expression of Cannabinoid Receptors (CB) Cnr) in the Rat Hippocampus}

Results from quantitative RT-PCR (qRT-PCR) that measured the mRNA expression of the cannabinoid receptors-CB1/ $C n r l$ and $C B 2 / C n r 2$ - are shown in Fig. 2a and b, respectively. One-way ANOVA analysis of the qRT-PCR data revealed significant changes in the expression of $C B 1 / C n r l$ $\left[F_{(4,37)}=5.618, p=0.0012\right]$ and $C B 2 / C n r 2\left[F_{(4,34)}=4.801\right.$, $p=0.003]$. Post hoc analyses revealed that these changes were due to significant increases in $\mathrm{CB} 1 / \mathrm{Cnrl}$ and $\mathrm{CB} 2 / \mathrm{Cnr} 2$ mRNA levels in the SS rats in comparison to CT, YSS, and SR rats (Fig. $2 b$ and c).

\section{Effects of METH SA and Contingent Footshock on mRNA Expression of Cannabinoid Enzymes in the Rat Hippocampus}

The effects of METH SA and footshock on the five key synthesizing enzymes that participate in the ECS signaling cascade systems are shown in Fig. 3. Among the synthesizing enzymes, we found significant changes in Dagla $\left[F_{(4,37)}=3.042, p=0.029\right]$ mRNA expression (Fig. 3b), with post hoc tests identifying increased Dagla expression in SS rats in comparison to the CT, YSS, and SR rats. No significant changes were observed in Napepld (Fig. 3a) and Daglb (Fig. 3c) mRNA expression.

The METH SA-induced alterations in mRNA levels of metabolizing enzymes of the ECS pathway identified significant changes in the expression of Faah $\left[F_{(4,36)}=5.857\right.$, $p=0.001]$ (Fig. 3d) and Mgll $\left[F_{(4,35)}=6.015, p=0.0009\right.$ ] (Fig. 3e). Post hoc analyses revealed significant increases in mRNA levels in the SS rats in comparison to YSS and SR rats. No significant changes was seen in the expression of $\operatorname{Ptgs} 2\left[F_{(4,33)}=0.976, p=0.4333\right]$ (Fig. 3f).

\section{Discussion}

The present study documents, for the first time, alterations in the expression of eCB genes in compulsive METH taking and non-compulsive rats divided after application of footshocks after all the rats had escalated their METH intake. Non-compulsive METH takers showed increased hippocampal mRNA expression of both cannabinoid receptors-CB1/Cnrl and $C B 2 / C n r 2-$ but exhibited no changes in the NAc and mid-brain (supplementary figure S1). They also exhibited increased hippocampal expression of Dagla, Mgll, and Faah enzymes but no

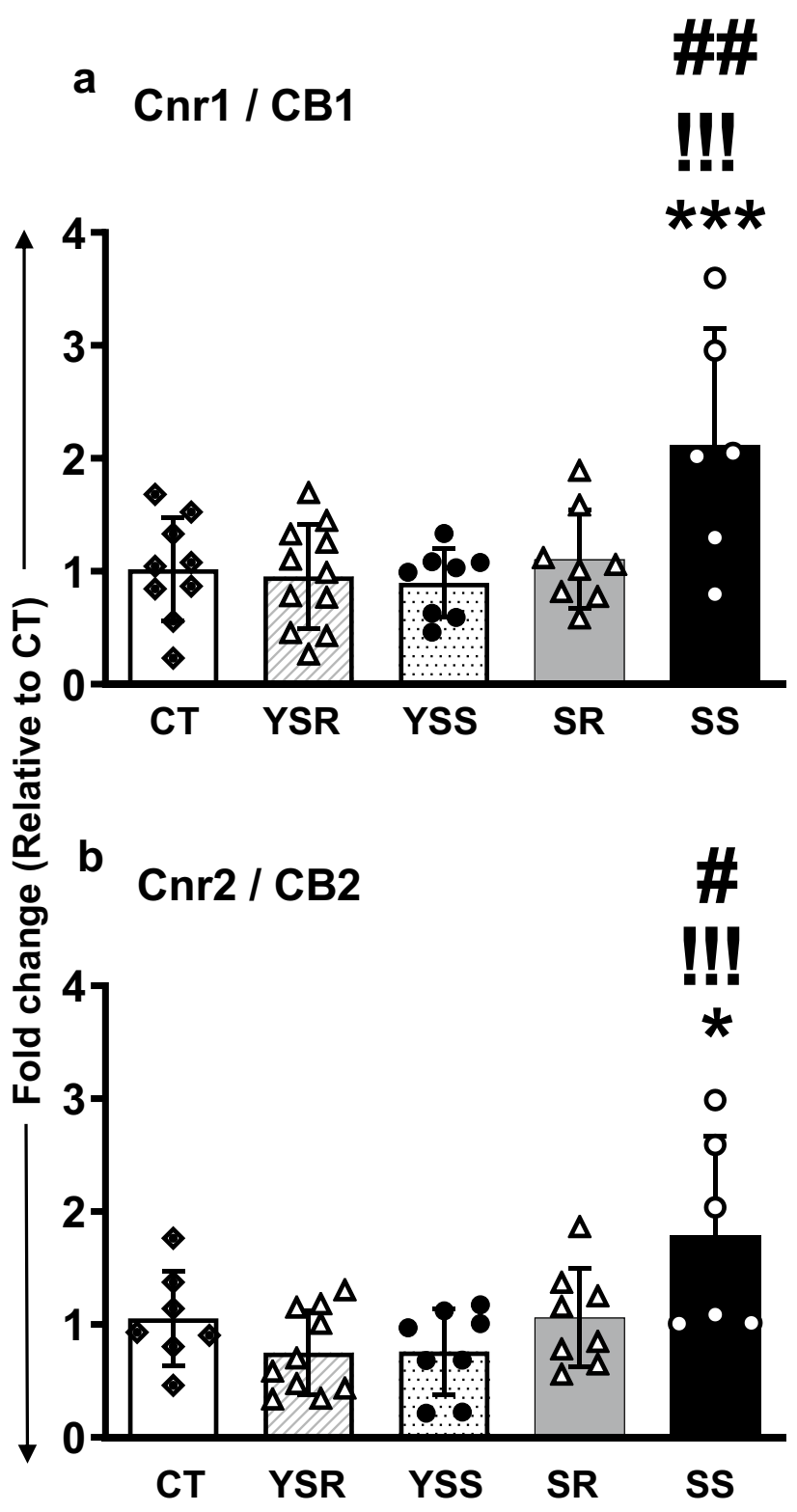

Fig. 2 Altered rat hippocampal mRNA expression of cannabinoid receptors $(\mathrm{CB} / \mathrm{Cnr})$ as a result of METH SA followed by contingent footshocks. Quantitative RT-PCR (qRT-PCR) data on the mRNA expression of the cannabinoid receptors, CB1/Cnrl (a) and CB2/ $\mathrm{Cnr} 2$ (b). One-way ANOVA analysis of the data revealed significant changes in CB1/Cnr1 expression $(p=0.0001)$ and CB2/Cnr2 expression $(p=0.0017)$. Post hoc analyses showed significant increases in both receptor mRNA levels in the SS group compared to the CT, YSS, and SR groups. Key to statistics: $* * P<0.01$, $* * * P<0.001$, compared with controls; !!! $P<0.001$, comparison to yoked shock sensitive (YSS); $\# P<0.05, \# \# P<<0.001$, comparison to compulsive METH (SR) group

alterations in the NAc and mid-brain (supplementary figure S2). Together, these observations support the idea that the hippocampal ECS signaling cascade may be specifically involved in some of the behavioral manifestations 
Fig. 3 Effect of METH SA and contingent footshock on rat hippocampal mRNA expression of key cannabinoid enzymes within the ECS cascade. Data from qRT-PCR showed significant increase in the mRNA expression of the synthesizing enzyme Dagla (b) in SS rats in comparison to CT, YSS, and $\mathrm{SR}$ rats $(p<0.01)$. Among the metabolizing enzymes, significant changes in the expression of Faah $(p=0.0004)$ and Mgll $(p=0.0015)$ were also observed where significant increases in mRNA levels were noted in the SS rats compared to the YSS, YSR, and SR rats. Significant decreases in Ptgs2 ( $p=0.0003)$ mRNA levels were noted in the SS, YSR, and YSS groups in comparison to the CT group. Key to statistics: $* P<0.05$, $* * P<0.01$, compared with controls; !!! $P<0.001$, comparison to yoked shock sensitive (YSS); $\# P<0.05$, \#\#P<0.01, comparison to compulsive METH (SR) group
Synthesizing Enzymes

$$
\text { a Napepld }
$$

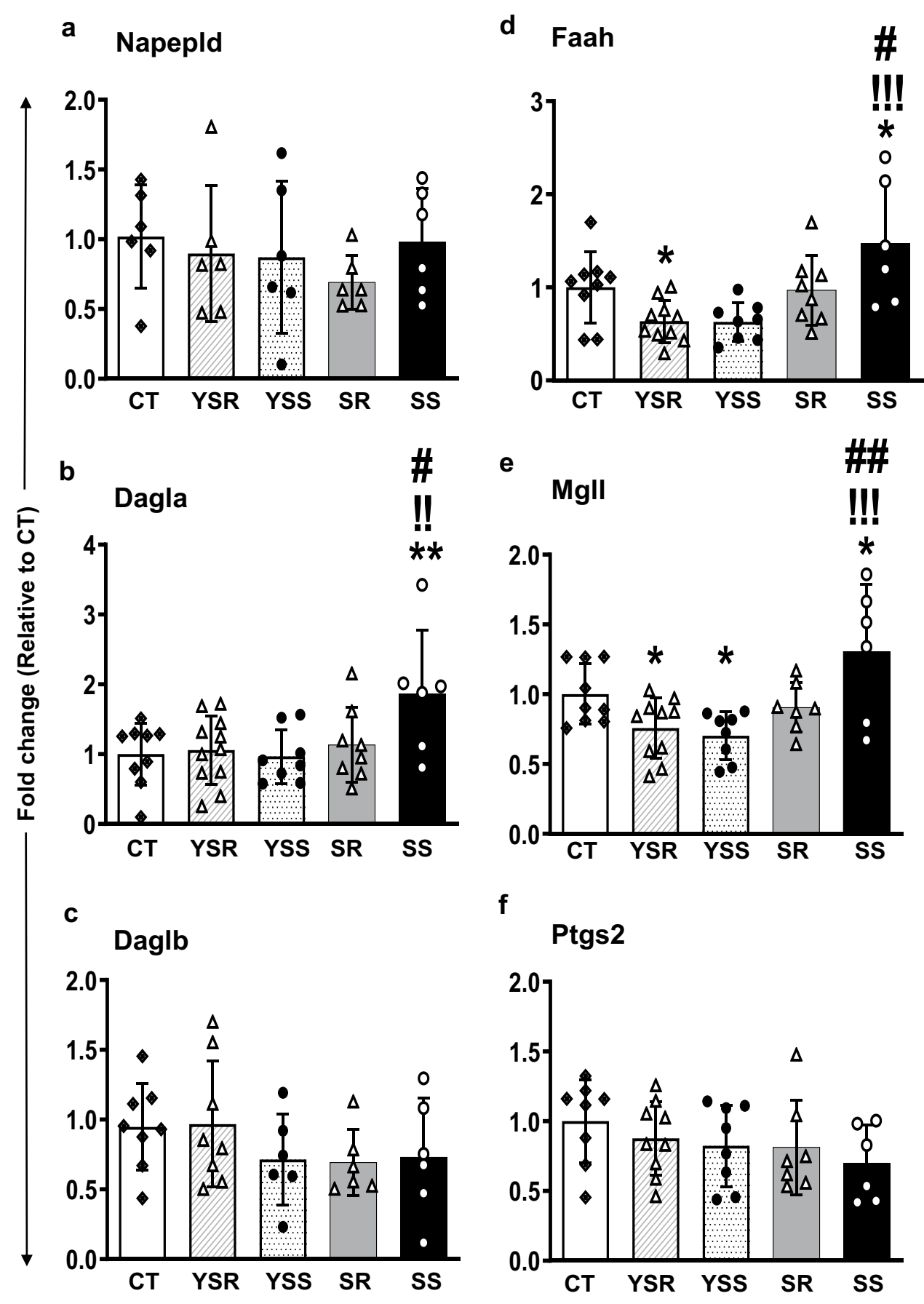

d Faah

Metabolic Enzymes of METH SA in animals and, by extension, METH use disorder (MUD) in humans [44-46].

Our findings of increased expression of hippocampal metabolizing enzymes, Mgll and Faah, are consistent, in part, with those of Blanco et al. [47] who had reported an increase in gene and protein expression of MGLL and FAAH in the hippocampus following both acute $(10 \mathrm{mg} /$ $\mathrm{kg})$ and repeated $(20 \mathrm{mg} / \mathrm{kg})$ cocaine administration for five consecutive days. These authors also reported increased $C B 1 / C n r l$ expression after cocaine [47]. Nevertheless, we found more changes in the non-compulsive (SS) rats that had significantly decreased their intake after punishment. These observations suggest that eCB signaling may be influenced by the differences in neuronal activity related to the quantities of METH taken by the two divergent groups. On the other hand, the changes might be 
Fig. 4 Schematic representation of a potential mechanism within the rat hippocampal ECS signaling cascade as a result of METH SA. (a) The rat brain is depicted with specific changes noted within the hippocampi of SS rats-increased levels of Cnr1, Cnr2, Faah, and Mgll.

(b) The schema helps to better understand the effect of the training and shock phases. For instance, SS rats had elevated levels of $\mathrm{Cnrl}$ and $C n r 2$ suggesting an upregulation of the receptor in order to combat the neurotoxic effects of dysregulated dopamine/ glutamate release due to METH intake. As a result, 2-AG and AEA, produced by DAGL and NAPEPLD, would increase and bind to these receptors to prevent excess release of these neurotransmitters. FAAH and MGLL then work to break down the excess endocannabinoids to prevent unnecessary activation of the cannabinoid receptors. Abbreviations: AA arachidonic acid, AC adenylate cyclase, PGH prostaglandin

a

Hippocampus SS: $\uparrow C n r 1, \uparrow C n r 2$, $\uparrow$ Faah, $\uparrow$ Mgll, $\uparrow$ Dagla

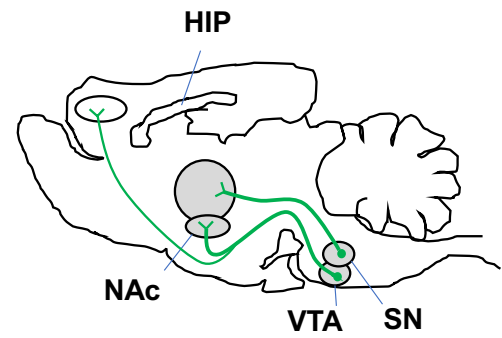

b

Schematic representation of the ECS signaling cascade changes at the molecular level after METH SA

DA Presynaptic Terminal

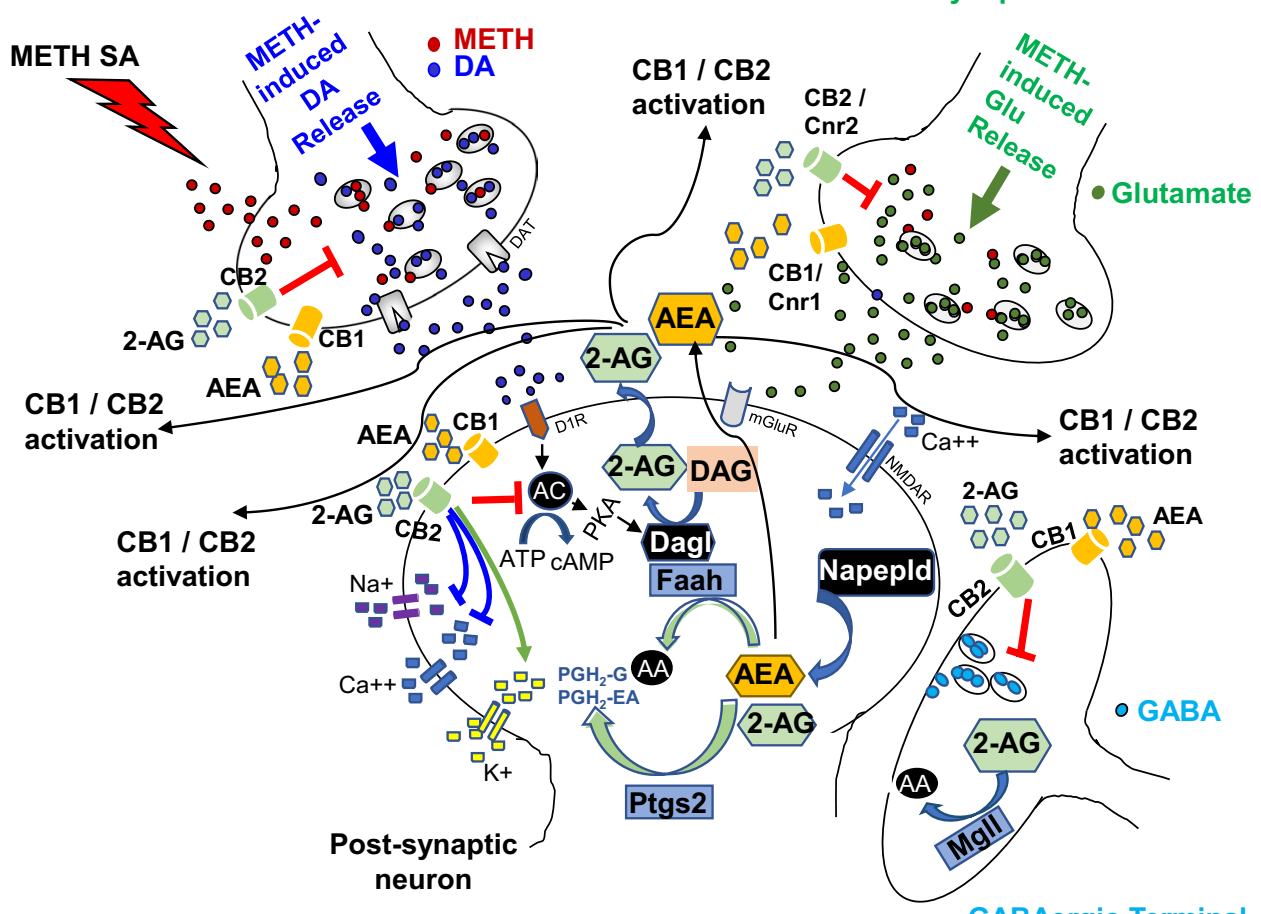

GABAergic Terminal

related to the ability of some rats to learn the association of lever pressing for METH with the application of footshocks. In fact, although all the rats had learned to selfadminister METH during the initial training phase, some of the rats seem to be more apt to learn the association of punishment with lever pressing for METH. These rats reduce their lever pressing activities whereas others might not have learned the association and continued to lever press despite the adverse consequences. This suggestion is consistent with the work of Marsicano et al. [48] who showed that blockade of CB1 receptor with the antagonist, SR141716, led to impaired extinction training after aversive stimulus. The discussion is also supported by Shiflett et al. [49] who also reported that intra-hippocampal infusion of SR141716 leads to increased memory but reduced flexibility and adaptation to new environmental conditions.

Our results suggest that exposure to METH can impact the hippocampal ECS. For example, stimulus-induced post-synaptic eCB formation is important in inducing neurogenesis [50, 51]. In addition, the participation of that system in the promotion of neurogenesis is supported by observations that cannabinoid receptor $C B 1 / C n r l-d e f i-$ cient animals showed decreased whereas FAAH-deficient ones showed increased proliferation of neural progenitor cells $[52,53]$. Interestingly, decreased neurogenesis in the hippocampus of rodents has been reported after exposure 
to METH SA [54]. Our findings of increased CB receptor expression suggest that there might be increased neurogenesis in animals that decreased their METH intake in the presence of footshocks since CB1-deficient rodents showed decreased neurogenesis $[52,53]$. This discussion is consistent with the results of Galinato et al. [55] that indicate the presence of increased neurogenesis during withdrawal from METH SA.

It is also possible that the increased CB mRNA levels in the non-compulsive rats might have served to suppress METH taking behaviors via inhibition of the release of glutamate [56, 57] which plays a role in drug SA [58-61]. The possibility that the increased expression of CB receptors might be due to compensatory increases secondary to decreased levels of eCBs because of METH-induced increases in their metabolism needs to be taken into consideration. This suggestion stems from our observations of increased expression of the metabolizing enzymes, $\mathrm{Mgll}$ and Faah, in the hippocampus of the non-compulsive rats. This supposition is consistent with the observations of Bystrowska et al. [62] who showed that exposure to cocaine SA for 14 days decreased hippocampal 2-AG, the MGLL substrate.

In contrast to our findings, URB597, an inhibitor of FAAH, was reported to suppress METH-seeking behavior in mice [63]. The dichotomous findings may be related to species differences since FAAH inhibition was found to increase nicotine [64] and alcohol reward [65] in mice, but reduced nicotine [66] or alcohol [67] reward in rats.

Our findings of increased hippocampal Dagla expression in the non-compulsive rats are consistent, in part, with the results of Mitra et al. [68] who reported increased levels of DAGL after prolonged abstinence (30 days) from cocaine SA. Together, these results suggest that abstinence for SA of psychostimulants may be accompanied by increased synthesis of 2-AG that might lead to increased synthesis of metabolizing enzymes in order to return the system back to homeostasis. These suggestions will need to be more thoroughly investigated by measuring the $\mathrm{eCB}$ levels in both the phenotypes.

In conclusion, we show, for the first time, that the endogenous ECS is significantly impacted in rats that had suppressed their METH intake in the presence of footshocks. Figure 4 shows a schematic illustration of the potential impact of METH SA on the ECS signaling cascade in the hippocampus. Future research is necessary to elucidate the potential role of the ECS in METH-induced changes in neurogenesis, oxidative stress, and neurodegenerative processes in various brain regions.

Supplementary Information The online version contains supplementary material available at https://doi.org/10.1007/s12035-021-02656-8.
Author Contribution J.L.C. and S.J. conceived the study and designed the methodology. S.J., R.P., B.L., and M.T.M performed the RT-PCR experiments. S.J. and R.P. analyzed the experimental data and wrote the first draft of the article. S.J., B.L., and M.T.M. performed the behavioral experiment. S.J. and J.L.C. reviewed the final manuscript.

Funding This paper is supported by the Intramural Research Program of the National Institute on Drug Abuse (NIDA), NIH, and DHHS [Grant \# DA000552 (2021)].

Data Availability All data generated and analyzed are included in this article.

\section{Declarations}

Ethical Statement. The rat experiments were carried out according to the guidelines outlined in the National Institutes of Health (NIH) Guide for the Care and Use of Laboratory Animals (ISBN: 978-0-309-154017) and the study was approved by the National Institute of Drug Abuse Animal Care and Use Committee.

Consent to Participate/Consent for Publication. Not applicable.

Conflict of Interest The authors declare no competing interests.

Open Access This article is licensed under a Creative Commons Attribution 4.0 International License, which permits use, sharing, adaptation, distribution and reproduction in any medium or format, as long as you give appropriate credit to the original author(s) and the source, provide a link to the Creative Commons licence, and indicate if changes were made. The images or other third party material in this article are included in the article's Creative Commons licence, unless indicated otherwise in a credit line to the material. If material is not included in the article's Creative Commons licence and your intended use is not permitted by statutory regulation or exceeds the permitted use, you will need to obtain permission directly from the copyright holder. To view a copy of this licence, visit http://creativecommons.org/licenses/by/4.0/.

\section{References}

1. Jones CM, Compton WM, Mustaquim D (2020) Patterns and characteristics of methamphetamine use among adults United States, 2015-2018. MMWR Morb Mortal Wkly Rep 69(12):317-323. https://doi.org/10.15585/mmwr.mm6912a1

2. Cadet JL, Krasnova IN (2009) Cellular and molecular neurobiology of brain preconditioning. Mol Neurobiol 39(1):50-61. https://doi.org/10.1007/s12035-009-8051-6

3. Sulzer D, Sonders MS, Poulsen NW, Galli A (2005) Mechanisms of neurotransmitter release by amphetamines: a review. Prog Neurobiol 75(6):406-433. https://doi.org/10.1016/j.pneur obio.2005.04.003

4. Beauvais G, Atwell K, Jayanthi S, Ladenheim B, Cadet JL (2011) Involvement of dopamine receptors in binge methamphetamine-induced activation of endoplasmic reticulum and mitochondrial stress pathways. PLoS ONE 6(12):e28946. https://doi.org/10.1371/journal.pone.0028946

5. Cadet JL, Jayanthi S, McCoy MT, Beauvais G, Cai NS (2010) Dopamine D1 receptors, regulation of gene expression in the brain, and neurodegeneration. CNS Neurol Disord Drug Targets 9(5):526-538 (BSP/CDTCNSND/E-Pub/00053 [pii]) 
6. Kujirai K, Carlson E, Epstein CJ, Cadet JL (1994) Autoradiographic distribution of mu opioid receptors in the brains of $\mathrm{Cu} /$ Zn-superoxide dismutase mice. Synapse 17(2):76-83. https://doi. org/10.1002/syn.890170203

7. Gluck MR, Moy LY, Jayatilleke E, Hogan KA, Manzino L, Sonsalla PK (2001) Parallel increases in lipid and protein oxidative markers in several mouse brain regions after methamphetamine treatment. J Neurochem 79(1):152-160. https://doi.org/10.1046/j. 1471-4159.2001.00549.x

8. Jayanthi S, Ladenheim B, Cadet JL (1998) Methamphetamineinduced changes in antioxidant enzymes and lipid peroxidation in copper/zinc-superoxide dismutase transgenic mice. Ann N Y Acad Sci 844:92-102

9. Cadet JL, Bisagno V, Milroy CM (2014) Neuropathology of substance use disorders. Acta Neuropathol 127(1):91-107. https:// doi.org/10.1007/s00401-013-1221-7

10. Mizoguchi H, Yamada K (2019) Methamphetamine use causes cognitive impairment and altered decision-making. Neurochem Int 124:106-113. https://doi.org/10.1016/j.neuint.2018.12.019

11 Mohammadkhani A, Borgland SL (2020) Cellular and behavioral basis of cannabinioid and opioid interactions: implications for opioid dependence and withdrawal. J Neurosci Res:jnr 2020:24770. https://doi.org/10.1002/jnr.24770

12. Sagheddu C, Torres LH, Marcourakis T, Pistis M (2020) Endocannabinoid-like lipid neuromodulators in the regulation of dopamine signaling: relevance for drug addiction. Front Synaptic Neurosci 12:588660. https://doi.org/10.3389/fnsyn.2020.588660

13. Parsons LH, Hurd YL (2015) Endocannabinoid signalling in reward and addiction. Nat Rev Neurosci 16(10):579-594. https:// doi.org/10.1038/nrn4004

14. Kruk-Slomka M, Dzik A, Budzynska B, Biala G (2017) Endocannabinoid system: the direct and indirect involvement in the memory and learning processes-a short review. Mol Neurobiol 54(10):8332-8347. https://doi.org/10.1007/s12035-016-0313-5

15. Wei D, Allsop S, Tye K, Piomelli D (2017) Endocannabinoid signaling in the control of social behavior. Trends Neurosci 40(7):385-396. https://doi.org/10.1016/j.tins.2017.04.005

16. Piomelli D (2014) More surprises lying ahead. The endocannabinoids keep us guessing. Neuropharmacology 76:228-234. https:// doi.org/10.1016/j.neuropharm.2013.07.026

17. Bisogno T, De Petrocellis L, Di Marzo V (2002) Fatty acid amide hydrolase, an enzyme with many bioactive substrates. Possible therapeutic implications. Curr Pharm Des 8(7):533-547. https:// doi.org/10.2174/1381612023395655

18. Dinh TP, Carpenter D, Leslie FM, Freund TF, Katona I, Sensi SL, Kathuria S, Piomelli D (2002) Brain monoglyceride lipase participating in endocannabinoid inactivation. Proc Natl Acad Sci 99(16):10819-10824. https://doi.org/10.1073/pnas.152334899

19 Hussain Z, Uyama T, Tsuboi K, Ueda N (2017) Mammalian enzymes responsible for the biosynthesis of N-acylethanolamines. Biochim Biophys Acta (BBA)-Molec Cell Biol Lipids 1862(12):1546-1561. https://doi.org/10.1016/j.bbalip.2017.08. 006

20. Reisenberg M, Singh PK, Williams G, Doherty P (2012) The diacylglycerol lipases: structure, regulation and roles in and beyond endocannabinoid signalling. Phil Trans R Soc B 367(1607):32643275. https://doi.org/10.1098/rstb.2011.0387

21 Urquhart P, Nicolaou A, Woodward DF (2015) Endocannabinoids and their oxygenation by cyclo-oxygenases, lipoxygenases and other oxygenases. Biochim Biophys Acta (BBA)-Molec Cell Biol Lipids 1851(4):366-376. https://doi.org/10.1016/j.bbalip.2014.12. 015

22. dos Santos RG, Hallak JEC, Crippa JAS (2021) Neuropharmacological effects of the main phytocannabinoids: a narrative review. In: Murillo-Rodriguez E, Pandi-Perumal SR, Monti JM (eds)
Cannabinoids and neuropsychiatric disorders, vol 1264. Springer International Publishing, Cham, pp 29-45

23. Augustin SM, Lovinger DM (2018) Functional relevance of endocannabinoid-dependent synaptic plasticity in the central nervous system. ACS Chem Neurosci 9(9):2146-2161. https://doi.org/10. 1021/acschemneuro.7b00508

24. Stella N, Schweitzer P, Piomelli D (1997) A second endogenous cannabinoid that modulates long-term potentiation. Nature 388(6644):773-778. https://doi.org/10.1038/42015

25. Xu JY, Chen C (2015) Endocannabinoids in synaptic plasticity and neuroprotection. Neuroscientist 21(2):152-168. https://doi. org/10.1177/1073858414524632

26. Panagis G, Mackey B, Vlachou S (2014) Cannabinoid regulation of brain reward processing with an emphasis on the role of CB1 receptors: a step back into the future. Front Psychiatry 5:92. https://doi.org/10.3389/fpsyt.2014.00092

27. Sidhpura N, Parsons LH (2011) Endocannabinoid-mediated synaptic plasticity and addiction-related behavior. Neuropharmacology 61(7):1070-1087. https://doi.org/10.1016/j.neuropharm. 2011.05.034

28. Hill MN, Patel S, Campolongo P, Tasker JG, Wotjak CT, Bains JS (2010) Functional interactions between stress and the endocannabinoid system: from synaptic signaling to behavioral output. J Neurosci 30(45):14980-14986. https://doi.org/10.1523/ JNEUROSCI.4283-10.2010

29. Lafenetre P, Chaouloff F, Marsicano G (2007) The endocannabinoid system in the processing of anxiety and fear and how CB1 receptors may modulate fear extinction. Pharmacol Res 56(5):367-381. https://doi.org/10.1016/j.phrs.2007.09.006

30. Metna-Laurent M, Soria-Gomez E, Verrier D, Conforzi M, Jego P, Lafenetre P, Marsicano G (2012) Bimodal control of fearcoping strategies by $\mathrm{CB}(1)$ cannabinoid receptors. J Neurosci 32(21):7109-7118. https://doi.org/10.1523/JNEUROSCI.105412.2012

31. Morena M, Roozendaal B, Trezza V, Ratano P, Peloso A, Hauer D, Atsak P, Trabace L, Cuomo V, McGaugh JL, Schelling G, Campolongo P (2014) Endogenous cannabinoid release within prefrontal-limbic pathways affects memory consolidation of emotional training. Proc Natl Acad Sci U S A 111(51):1833318338. https://doi.org/10.1073/pnas.1420285111

32. Kim J, Alger BE (2004) Inhibition of cyclooxygenase-2 potentiates retrograde endocannabinoid effects in hippocampus. Nat Neurosci 7(7):697-698. https://doi.org/10.1038/nn1262

33. Kim J, Alger BE (2010) Reduction in endocannabinoid tone is a homeostatic mechanism for specific inhibitory synapses. Nat Neurosci 13(5):592-600. https://doi.org/10.1038/nn.2517

34. Pan B, Wang W, Zhong P, Blankman JL, Cravatt BF, Liu QS (2011) Alterations of endocannabinoid signaling, synaptic plasticity, learning, and memory in monoacylglycerol lipase knockout mice. J Neurosci 31(38):13420-13430. https://doi.org/10. 1523/JNEUROSCI.2075-11.2011

35. Straiker A, Hu SS, Long JZ, Arnold A, Wager-Miller J, Cravatt BF, Mackie K (2009) Monoacylglycerol lipase limits the duration of endocannabinoid-mediated depolarization-induced suppression of excitation in autaptic hippocampal neurons. Mol Pharmacol 76(6):1220-1227. https://doi.org/10.1124/mol.109. 059030

36. Straiker A, Wager-Miller J, Hu SS, Blankman JL, Cravatt BF, Mackie K (2011) COX-2 and fatty acid amide hydrolase can regulate the time course of depolarization-induced suppression of excitation. Br J Pharmacol 164(6):1672-1683. https://doi.org/ 10.1111/j.1476-5381.2011.01486.x

37. Cadet JL (2019) Animal models of addiction: compulsive drug taking and cognition. Neurosci Biobehav Rev 106:5-6. https:// doi.org/10.1016/j.neubiorev.2019.05.026 
38. Cadet JL, Brannock C, Krasnova IN, Jayanthi S, Ladenheim B, McCoy MT, Walther D, Godino A, Pirooznia M, Lee RS (2017) Genome-wide DNA hydroxymethylation identifies potassium channels in the nucleus accumbens as discriminators of methamphetamine addiction and abstinence. Mol Psychiatry 22(8):11961204. https://doi.org/10.1038/mp.2016.48

39. Krasnova IN, Gerra MC, Walther D, Jayanthi S, Ladenheim B, McCoy MT, Brannock C, Cadet JL (2017) Compulsive methamphetamine taking in the presence of punishment is associated with increased oxytocin expression in the nucleus accumbens of rats. Sci Rep 7(1):8331. https://doi.org/10.1038/s41598-017-08898-8

40. Subu R, Jayanthi S, Cadet JL (2020) Compulsive methamphetamine taking induces autophagic and apoptotic markers in the rat dorsal striatum. Arch Toxicol 94(10):3515-3526. https://doi.org/ 10.1007/s00204-020-02844-w

41. Krasnova IN, Marchant NJ, Ladenheim B, McCoy MT, Panlilio LV, Bossert JM, Shaham Y, Cadet JL (2014) Incubation of methamphetamine and palatable food craving after punishmentinduced abstinence. Neuropsychopharmacol 39(8):2008-2016. https://doi.org/10.1038/npp.2014.50

42. Torres OV, Jayanthi S, Ladenheim B, McCoy MT, Krasnova IN, Cadet JL (2017) Compulsive methamphetamine taking under punishment is associated with greater cue-induced drug seeking in rats. Behav Brain Res 326:265-271. https://doi.org/10.1016/j. bbr.2017.03.009

43. Jayanthi S, Deng X, Noailles PA, Ladenheim B, Cadet JL (2004) Methamphetamine induces neuronal apoptosis via cross-talks between endoplasmic reticulum and mitochondria-dependent death cascades. FASEB J 18(2):238-251. https://doi.org/10. 1096/fj.03-0295com18/2/238

44. Huang X, Chen YY, Shen Y, Cao X, Li A, Liu Q, Li Z, Zhang LB, Dai W, Tan T, Arias-Carrion O, Xue YX, Su H, Yuan TF (2017) Methamphetamine abuse impairs motor cortical plasticity and function. Mol Psychiatry 22(9):1274-1281. https://doi. org/10.1038/mp.2017.143

45. Recinto P, Samant ARH, Chavez G, Kim A, Yuan CJ, Soleiman M, Grant Y, Edwards S, Wee S, Koob GF, George O, Mandyam CD (2012) Levels of neural progenitors in the hippocampus predict memory impairment and relapse to drug seeking as a function of excessive methamphetamine self-administration. Neuropsychopharmacol 37(5):1275-1287. https://doi.org/10. 1038/npp.2011.315

46. Yuan CJ, Quiocho JMD, Kim A, Wee S, Mandyam CD (2011) Extended access methamphetamine decreases immature neurons in the hippocampus which results from loss and altered development of neural progenitors without altered dynamics of the S-phase of the cell cycle. Pharmacol Biochem Behav 100(1):98-108. https://doi.org/10.1016/j.pbb.2011.08.004

47. Blanco E, Galeano P, Palomino A, Pavón FJ, Rivera P, Serrano A, Alen F, Rubio L, Vargas A, Castilla-Ortega E, Decara J, Bilbao A, de Fonseca FR, Suárez J (2016) Cocaine-induced behavioral sensitization decreases the expression of endocannabinoid signaling-related proteins in the mouse hippocampus. Eur Neuropsychopharmacol 26(3):477-492. https://doi.org/10. 1016/j.euroneuro.2015.12.040

48. Marsicano G, Wotjak CT, Azad SC, Bisogno T, Rammes G, Cascio MG, Hermann H, Tang J, Hofmann C, Zieglgansberger W, Di Marzo V, Lutz B (2002) The endogenous cannabinoid system controls extinction of aversive memories. Nature 418(6897):530-534. https://doi.org/10.1038/nature00839

49. Shiflett MW, Rankin AZ, Tomaszycki ML, DeVoogd TJ (2004) Cannabinoid inhibition improves memory in food-storing birds, but with a cost. Proc Biol Sci 271(1552):2043-2048. https://doi. org/10.1098/rspb.2004.2823

50. Mlost J, Wąsik A, Starowicz K (2019) Role of endocannabinoid system in dopamine signalling within the reward circuits affected by chronic pain. Pharmacol Res 143:40-47. https://doi. org/10.1016/j.phrs.2019.02.029

51. Wu Y, Liu Q, Guo B, Ye F, Ge J, Xue L (2020) BDNF activates postsynaptic TrkB receptors to induce endocannabinoid release and inhibit presynaptic calcium influx at a calyx-type synapse. J Neurosci 40(42):8070-8087. https://doi.org/10.1523/JNEUR OSCI.2838-19.2020

52. Aguado T (2006) The endocannabinoid system promotes astroglial differentiation by acting on neural progenitor cells. J Neurosci 26(5):1551-1561. https://doi.org/10.1523/JNEUROSCI. 3101-05.2006

53. Mechoulam R, Parker LA (2013) The endocannabinoid system and the brain. Annu Rev Psychol 64(1):21-47. https://doi.org/ 10.1146/annurev-psych-113011-143739

54. Galinato MH, Orio L, Mandyam CD (2015) Methamphetamine differentially affects BDNF and cell death factors in anatomically defined regions of the hippocampus. Neuroscience 286:97-108. https://doi.org/10.1016/j.neuroscience.2014.11.042

55. Galinato MH, Takashima Y, Fannon MJ, Quach LW, Morales Silva RJ, Mysore KK, Terranova MJ, Dutta RR, Ostrom RW, Somkuwar SS, Mandyam CD (2018) Neurogenesis during abstinence is necessary for context-driven methamphetamine-related memory. J Neurosci 38(8):2029-2042. https://doi.org/10.1523/ JNEUROSCI.2011-17.2018

56. Köfalvi A, Moreno E, Cordomí A, Cai N-S, Fernández-Dueñas V, Ferreira SG, Guixà-González R, Sánchez-Soto M, Yano H, Casadó-Anguera V, Cunha RA, Sebastião AM, Ciruela F, Pardo L, Casadó V, Ferré S (2020) Control of glutamate release by complexes of adenosine and cannabinoid receptors. BMC Biol 18(1):9. https://doi.org/10.1186/s12915-020-0739-0

57. Maier N, Morris G, Schuchmann S, Korotkova T, Ponomarenko A, Böhm C, Wozny C, Schmitz D (2012) Cannabinoids disrupt hippocampal sharp wave-ripples via inhibition of glutamate release. Hippocampus 22(6):1350-1362. https://doi.org/10.1002/hipo. 20971

58. Li X, Rubio FJ, Zeric T, Bossert JM, Kambhampati S, Cates HM, Kennedy PJ, Liu QR, Cimbro R, Hope BT, Nestler EJ, Shaham $Y$ (2015) Incubation of methamphetamine craving is associated with selective increases in expression of Bdnf and Trkb, glutamate receptors, and epigenetic enzymes in cue-activated Fos-expressing dorsal striatal neurons. J Neurosci 35(21):8232-8244. https://doi. org/10.1523/JNEUROSCI.1022-15.2015

59. Mishra D, Pena-Bravo JI, Leong K-C, Lavin A, Reichel CM (2017) Methamphetamine self-administration modulates glutamate neurophysiology. Brain Struct Funct 222(5):2031-2039. https://doi.org/10.1007/s00429-016-1322-x

60. Murray CH, Loweth JA, Milovanovic M, Stefanik MT, Caccamise AJ, Dolubizno H, Funke JR, Foster Olive M, Wolf ME (2019) AMPA receptor and metabotropic glutamate receptor 1 adaptations in the nucleus accumbens core during incubation of methamphetamine craving. Neuropsychopharmacol 44(9):1534-1541. https://doi.org/10.1038/s41386-019-0425-5

61 Pena-Bravo JI, Penrod R, Reichel CM, Lavin A (2019) Methamphetamine self-administration elicits sex-related changes in postsynaptic glutamate transmission in the prefrontal cortex. eNeuro 6(1):ENEURO.0401-18.2018. https://doi.org/10.1523/ENEURO. 0401-18.2018

62. Bystrowska B, Smaga I, Frankowska M, Filip M (2014) Changes in endocannabinoid and $\mathrm{N}$-acylethanolamine levels in rat brain structures following cocaine self-administration and extinction training. Prog Neuropsychopharmacol Biol Psychiatry 50:1-10. https://doi.org/10.1016/j.pnpbp.2013.12.002

63. Ebrahimi-Ghiri M, Khakpai F, Zarrindast MR (2021) URB597 abrogates anxiogenic and depressive behaviors in the methamphetamine-withdrawal mice: role of the cannabinoid receptor type 1 , cannabinoid receptor type 2 , and transient receptor potential 
vanilloid 1 channels. J Psychopharmacol 35(7):875-884. https:// doi.org/10.1177/0269881120965934

64. Muldoon PP, Lichtman AH, Parsons LH, Damaj MI (2013) The role of fatty acid amide hydrolase inhibition in nicotine reward and dependence. Life Sci 92(8-9):458-462. https://doi.org/10.1016/j. lfs.2012.05.015

65. Blednov YA, Cravatt BF, Boehm SL 2nd, Walker D, Harris RA (2007) Role of endocannabinoids in alcohol consumption and intoxication: studies of mice lacking fatty acid amide hydrolase. Neuropsychopharmacol 32(7):1570-1582. https://doi.org/10. 1038/sj.npp.1301274

66. Scherma M, Panlilio LV, Fadda P, Fattore L, Gamaleddin I, Le Foll B, Justinova Z, Mikics E, Haller J, Medalie J, Stroik J, Barnes C, Yasar S, Tanda G, Piomelli D, Fratta W, Goldberg SR (2008) Inhibition of anandamide hydrolysis by cyclohexyl carbamic acid 3'-carbamoyl-3-yl ester (URB597) reverses abuse-related behavioral and neurochemical effects of nicotine in rats. J Pharmacol Exp Ther 327(2):482-490. https://doi.org/10.1124/jpet.108. 142224
67. Cippitelli A, Cannella N, Braconi S, Duranti A, Tontini A, Bilbao A, Defonseca FR, Piomelli D, Ciccocioppo R (2008) Increase of brain endocannabinoid anandamide levels by FAAH inhibition and alcohol abuse behaviours in the rat. Psychopharmacology 198(4):449-460. https://doi.org/10.1007/s00213-008-1104-0

68. Mitra S, Gobira PH, Werner CT, Martin JA, Iida M, Thomas SA, Erias K, Miracle S, Lafargue C, An C, Dietz DM (2021) A role for the endocannabinoid enzymes monoacylglycerol and diacylglycerol lipases in cue-induced cocaine craving following prolonged abstinence. Addict Biol. https://doi.org/10.1111/adb.13007

Publisher's Note Springer Nature remains neutral with regard to jurisdictional claims in published maps and institutional affiliations. 